Jurnal InFestasi

Vol. 11, No.2, Desember 2015

Hal. $137-150$

\title{
ANALISIS KINERJA DALAM PERSPEKTIF POLICAL ECONOMY OF ACCOUNTING (STUDI KASUS PDAM MAJU)
}

\author{
Bambang Haryadi \\ FE Universitas Trunojoyo Madura
}

\begin{abstract}
In the process, gain or loss PDAM has been a key indicator in assessing the performance of a company. The impact of this understanding is that many companies are doing financial engineering in order to look good financial performance. As a public company, the performance of PDAM Maju can not be assessed only from a financial point of view only. Need to understand the performance of PDAM Maju from a more meaningful perspective in order to obtain a more thorough understanding of the performance.

Analysis tools of critical accounting that uses the framework of Political Economy of Accounting (PEA) aimed to understand and evaluate the role of accounting in the context of economic, social and political. Losses incurred during the company is described as fatamurgana. It seems the company suffered losses, but the actual loss is not the case in real terms. The company's performance is always influenced by various political factors and the lack of the role of power companies .
\end{abstract}

Keywords: PEA, Performance, Loss of PDAM

\begin{abstract}
Abstrak
Dalam perjalanannya, laba atau rugi PDAM menjadi indikator kunci dalam menilai kinerja perusahaan. Dampak pemahaman ini adalah banyak perusahaan yang melakukan rekayasa keuangan agar kinerja keuangannya terlihat baik. Sebagai perusahaan publik, kinerja PDAM Maju tidak dapat hanya dinilai dari aspek keuangan saja. Diperlukan pemahaman tentang kinerja PDAM Maju dari perspektif yang lebih bermakna untuk mendapatkan pemahaman kinerja secara utuh.

Alat analisis akuntansi kritis yang menggunakan rerangka Political Economy of Accounting (PEA) bertujuan memahami dan menilai peran akuntansi dalam konteks ekonomi, sosial dan politik. Kerugian perusahaan yang terjadi diibaratkan sebagai sebuah fatamurgana. Sepertinya perusahaan mengalami kerugian, namun sesungguhnya kerugian tersebut tidak terjadi secara riil. Kinerja perusahaan senantiasa dipengaruhi oleh berbagai faktor politik dan kurangnya peran kekuasaan perusahaan.
\end{abstract}

Kata Kunci: PEA, Kinerja, Kerugian PDAM

\section{PENDAHULUAN}

Salah satu informasi penting dari laporan keuangan yang sering digunakan pengguna dalam pengambilan keputusan adalah kinerja perusahaan. Kinerja ini bersumber dari laporan keuangan dan merupakan cerminan kekuatan perusahaan. Kinerja merupakan ukuran yang dapat menilai keberhasilan suatu perusahaan dalam menghasilkan laba (Sucipto, 2003:2) ; (SAK: 2009:5 Par 17).

Pernyataan di atas mengandung makna bahwa (1) kinerja perusahaan lebih ditekankan pada kemampuan perusahaan dalam menghasilkan laba atau profitabilitas, (2) informasi kinerja sangat penting dalam mengukur efektifitas perusahaan dalam mengelola sumberdaya ekonomi secara potensial, memprediksi kemampuan usaha perusahaan di masa sekarang dan di masa yang akan dating, (3) informasi kinerja, khususnya laba dapat diperoleh dari informasi laporan keuangan perusahaan.

Penempatan laba sebagai indikator utama kinerja, didukung oleh 
pendekatan akuntansi positif. Dalam pendekatan akuntansi positif, laba merupakan cerminan realisme fisik dan sebagai potret atas fakta-fakta sosial yang bebas nilai (Ghozali, 2004). Bebas nilai berarti bebas dari nilai ilmu pengetahuan, pengalarnan, sifat, kepentingan dan nilai masyarakat (Triyuwono: 2000), nilai agama, sosial, moral, politik, kepentingan dan nilai ekonomi (Ayudhia: 2008), dimana seluruhnya melekat secara inheren dalam diri akuntan yang menyusun angka tersebut.

Angka laba dianggap sangat objektif dan netral menggambarkan kondisi perusahaan secara riil. Pemahaman ini sekaligus mengokohkan posisi laba sebagai angka "krusial" dan "terpercaya". Angka ini benar-benar diyakini dan dipercaya dapat membantu para pengguna laporan keuangan dalam membuat keputusan ekonomi di masa yang akan datang secara lebih objektif dan netral.

Kecenderungan ini menyebabkan banyak perusahaan berlomba-lomba merekaya kinerja agar lebih baik di mata investor, kreditor, calon investor maupun masyarakat secara umum. Beberapa contoh kasus besar kejahatan keuangan yang terjadi di korporasi dengan menggunakan teknik-teknik manipulasi dan rekayasa laporan keuangan misalnya kasus Xerox tahun 1986, Enron pada tahun 2001, Worldcom tahun 2002, dan Global Crossing dan Adelthin di Amerika Serikat. Semua adalah perusahaan besar yang dalam waktu sekejap hancur dikarenakan adanya skandal akuntansi (Kompas, 2002). Tahun 2008 kasus Lehman Brother yang merekayasa akuntansi untuk menutupi utang sebesar 50 miliar dolar AS di pembukuannya (Suara Karya, 2010).

Kasus di atas menjadi bukti bahwa tidak benar angka kinerja adalah bebas nilai dan objektif. Kenyataannya, laporan keuangan yang merupakan ukuran kinerja sangat sarat dengan nilai (nilai ekonomi, moral, budaya, politik, kepentingan, agama, sosial, dan lingkungan). Akuntansi dan kinerja tidak dapat berdiri sendiri dari lingkungan di mana akuntansi itu dioperasikan. Kinerja dan Akuntansi senantiasa dipengaruhi oleh lingkungannya (Hopwood 1983, 1987, 1990; Morgan 1988; Miller dan Napter 1993).

Karena realitas menunjukkan bahwa angka kinerja sarat dengan nilai dan subjektif, maka sudah seharusnya menilai dan memahami kinerja suatu perusahaan tidak hanya dilihat dari angka yang tersaji dalam laporan keuangan, namun pada proses penciptaan angka-angka itu serta bagaimana dampak angka itu bagi seluruh pihak baik yang langsung dan tidak langsung berkontribusi terhadap perusahaan. Bagi perusahaan publik, kompleksitas permasalahan semakin luas karena banyak pihak yang memiliki kepentingan terhadap perusahaan. Nuansa kepentingan ekonomi, kepentingan politik dan kepentingan lain dari berbagai pihak muncul dan menyatu dalam perusahaan publik. Maka sangat tepat jika dalam penelitian ini perusahaan air (PDAM) dijadikan sebagai objek penelitian untuk mengungkap pengaruh-pengaruh serta kepentingankepentingan yang ada dalam kinerja yang dihasilkan.

Tabel 1. Perkembangan Kinerja PDAM di Indonesia

\begin{tabular}{cl}
\hline Tahun & \multicolumn{1}{c}{ Nilai Kinerja } \\
\hline 2001 & 93\% (186 dari 201) PDAM kesulitan melunasi hutang (Kompas, 16 pebr) \\
2003 & $91 \%$ PDAM masuk kategori tidak sehat (Kompas, 4 sept) \\
2004 & 90\% PDAM masuk kategori tidak sehat (Tempo Interaktif, 27 Apr) \\
2005 & PDAM mengalami kerugian rata-rata Rp 100 miliar pertahun (Lintkang, \\
& 2005), 90\% PDAM masuk kategori sakit (Tempo Interaktif, 5 Juli) \\
2006 & 330 dari 335 PDAM memiliki kekayaan negative (Kompas, 27 Ags) \\
2007 & 44 dari 335 PDAM yang dinilai sehat (Kompas mobile, 28 Ags) \\
2008 & 80 dari 335 PDAM masuk kategori sehat (24\%), tingkat kehilangan air rata- \\
& rata 37\% (Kompas, 27 Ags)
\end{tabular}

Sumber: Berbagai data diolah 
Data kinerja PDAM tersaji dalam Tabel 1 dan menunjukkan bahwa PDAM di Indonesia mengalami kinerja yang rendah. Sejak tahun 1962 hingga saat ini, kinerja tidak kunjung menunjukkan hasil yang menggembirakan. Lebih dari $80 \%$ PDAM mengalami kerugian dan selalu mengalami kesulitan keuangan, meskipun bentuk perusahaan adalah monopoli.

Hasil riset bahwa PDAM di Indonesia memiliki banyak masalah dan berkinerja rendah secara intens dilakukan oleh Wijaya (2003; 2004; 2005). Hasil penelitiannya menunjukkan bahwa (1) telah terjadi gap regulasi harga air yang ditetapkan oleh departemen dalam negeri dan PDAM serta pemerintah daerah, (2) telah terjadi ketidakefisienan dalam pengelolaan operasional perusahaan air minum (PDAM) sehingga berdampak pada tarif air yang mahal. (3) dalam rangka melayani masyarakat akan kebutuhan air yang layak masih belum mampu menunjukkan pelayanan yang memiliki rasa keadilan dan sosial yang tinggi.

Berdasarkan Tabel 1 dan hasil riset Wijaya (2003 dan 2004), jika kinerja perusahaan berfokus pada laba, maka tidak salah jika masyarakat menyimpulkan bahwa kinerja PDAM di Indonesia secara umum sangat rendah dan tidak efisien. Namun demikian, penilaian dan pemahaman ini menjadi bias dan tidak bijak jika sudut pandangnya tidak hanya berdasarkan angka-angka akuntansi yang tersaji.

Dengan demikian tidak cukup memahami kinerja hanya dari aspek keuangan saja. Diperlukan analisis yang lebih luas dari sekedar aspek keuangan dalam menilai dan memahami kinerja suatu perusahaan. Alat analisis yang lebih luas dan mampu menyediakan informasi secara lengkap dalam menilai dan memahami kinerja suatu perusahaan. Alat analisis berupa akuntansi kritis yang menggunakan rerangka Political Economy of Accounting (PEA) ditujukan untuk memahami sekaligus melakukan evaluasi atas peran akuntansi dalam konteks ekonomi, sosial dan politik atau mengkaji bagaimana peran akuntansi dalam konteks tertentu, baik organisasional maupun lingkungan yang lebih luas (Irianto, 2006: 145).

Sudah menjadi rahasia umum jika PDAM dinilai sebagai perusahaan yang berkinerja rendah. Hal tersebut didukung data yang menunjukkan bahwa kinerja PDAM di Indonesia berdasarkan perspektif ekonomi mengalami masalah yang sangat serius. Hanya sekitar 20\% PDAM yang bisa dikategorikan memiliki laba. Sedangkan selebihnya 80\% perusahaan mengalami kerugian secara kontinyu selama beberapa tahun terakhir (Tempo Interaktif, 2005).

Namun demikian kinerja PDAM yang rendah tidak bisa dilepaskan begitu saja dari faktor-faktor internal dan eksternal yang mempengaruhinya. Permasalahan kinerja PDAM merupakan masalah yang kompleks. Hal ini mengandung maksud bahwa kinerja PDAM yang rendah tidak semata-mata karena kesalahan pihak manajemen. Kompleksitas kinerja ini dapat dilihat dari beberapa permasalahan yang terjadi pada perusahaan ini.

Mengingat betapa kompleks permasalahan kinerja PDAM dan penuh dengan makna, nilai dan kepentingan yang sulit dilihat maka diperlukan sebuah perspektif yang dapat memotret secara utuh dan komprehensif. Perspektif ekonomi saja tampaknya tidak cukup untuk menilai kinerja dan mencari jawaban problematika kinerja PDAM. Diperlukan sebuah perspektif analisis yang dapat melibatkan beberapa aspek lain selain ekonomi misalnya dari aspek budaya, politik, hukum, sosial dan juga aspek pertahanan dan keamanan secara komprehensif. Oleh karena itu, permasalahanan penelitian yang bisa dirumuskan adalah Bagaimanakah kinerja Perusahaan Daerah Air Minum (PDAM) jika dianalisis dari perspektif Political Economy of Accounting.

Dengan demikian, tujuan penelitian ini adalah untuk menganalisis dan memahami kinerja Perusahaan Daerah Air Minum (PDAM) "Maju" secara komprehensif melalui perspektif Political Economy of Accounting (PEA). 


\section{METODE PENELITIAN}

\section{Paradigma dan Pendekatan Penelitian}

Penelitian ini menggunakan paradigma kualitatif (Indriantoro, 1999:12) atau pendekatan naturalistik, konstruktifis, interpelatif atau perspektif postmodern. Paradigma ini dibangun berlandaskan paradigma fenomenologis dari Edmund Husserl (1859-1926). Penelitian ini berupaya mengungkap relasi kekuasaan (power) dan fenomena hutang (ekonomi) PDAM.

Studi ini di dasarkan pada teori kritis yaitu salah satu pendekatan dalam paradigma kualitatif disamping pendekatan interpretif dan postmodernis (Chua, 1986; Burrel \& Morgan, 1979). Teori kritis berupaya mencari makna di balik yang empiris, dan menolak adanya konsep valuefree. Teori kritis mempunyai komitmen yang tinggi kepada tata sosial yang lebih adil. Asumsi dasarnya adalah bahwa ilmu sosial bukan sekedar memahami ketidakadilan dalam distribusi kekuasaan dan distribusi resources, melainkan berupaya untuk membantu menciptakan kesamaan dan emansipasi dalam kehidupan. Teori kritis ini memiliki keterikatan moral untuk mengkritik status quo dan membangun masyarakat yang lebih adil (Muhadjir, 2000: 197).

Tujuan teori kritis adalah menghilangkan berbagai bentuk dominasi dan mendorong kebebasan, keadilan dan persamaan. Teori ini menggunakan metode reflektif dengan cara mengkritik secara terus-menerus terhadap tatanan atau institusi sosial, politik atau ekonomi yang ada, dimana cenderung tidak kondusif bagi pencapaian kebebasan, keadilan, dan persamaan (Dougherty \& Robert, 1981).

Political Economy of Accounting (PEA) merupakan salah satu dari pendekatan teori kritik (critical theoritical approaches). PEA ini pertama kali diperkenalkan oleh Tinker (1980) dalam artikelnya yang berjudul "Towards a political economy of accounting: an empirical illustration of the cambridge controversies". Selanjutnya kajian PEA ini berkembang dengan munculnya penelitipeneliti lain yaitu Cooper and Sherer (1984), Tinker (1984), Neimark and
Tinker (1986), Willmot (1986), Armstrong (1987), Hopper et al. (1987), Shaoul (1997a, 1997b), Catchpowle et al. (2004), Irianto (2004).

PEA mencoba untuk menghadirkan sebuah kajian yang menghubungkan perspektif ekonomi dan politik dalam menganalisis realitas perusahaan berdasarkan informasi akuntansi yang tersaji dalam laporan keuangan perusahaan. PEA (Hopwood, 1978; Burchell et al., 1980; Neimark and Tinker, 1986) berupaya untuk memahami dan mengevaluasi fungsi akuntansi dalam konteks lingkungan ekonomi, sosial dan politik dimana akuntansi tersebut di terapkan.

\section{Data dan Informan}

Data kualitatif dalam penelitian ini diperoleh dari informan melalui observasi atau wawancara yang telah dilakukan. Data dan informasi yang merupakan sumber data utama penelitian ini berkenaan dengan laba (rugi) perusahaan (PDAM). Selain itu, informasi juga diperoleh dari sumber laporan, dokumen, foto dan bahan statistik terkait dengan laba (rugi) yang dimiliki PDAM. Sumber data ini merupakan sumber data kedua, namun tetap tidak bisa diabaikan (Moleong, 2005:159; Lofland, 1985:47; Nasution, 1996: 85).

Data dokumentasi, bahan statistik dan laporan laba (rugi) PDAM, dikumpulkan dari PDAM MAJU, dan berbagai sumber terpercaya misalnya Persatuan Perusahaan Air Minum Seluruh Indonesia (Perpamsi), Biro Pusat Statistik (BPS) kota MAJU, Bagian Keuangan Pemerintah Daerah Kabupaten MAJU, serta beberapa tulisan-tulisan atau artikel yang mengungkap data sejenis. Data yang telah dikumpulkan tidak hanya yang bersifat sekunder namun juga yang bersifat primer, bersifat kuantitatif maupun yang bersifat kualitatif.

Dalam riset ini peneliti mengumpulkan data secara langsung ke perusahaan dan tinggal di kota tersebut dalam beberapa waktu. Peneliti bisa mendapatkan data dengan leluasa dan cukup lengkap karena termasuk dalam salah satu anggota tim audit perusahaan tersebut. Peneliti berperan sebagai 
instrumen utama yang terjun ke lapangan, berusaha sendiri mengumpulkan informasi melalui observasi atau wawancara. Wawancara yang dilakukan dalam penelitian ini bersifat terbuka dan tidak terstruktur.

Informan dalam penelitian ini dilakukan dengan menggunakan snow ball sampling yang merupakan cara menentukan informan yang dilakukan pada saat wawancara mendalam dari informan ke informan lainnya hingga informasi atau data yang disampaikan menyerupai atau tidak ada perbedaan dengan informasi sebelumnya. Dengan demikian maka jumlah informan penelitian menggunakan pertimbangan snow-ball sampling yang berarti jumlahnya mengikuti perkembangan informasi atau data yang diperlukan untuk menjawab pertanyaan penelitian ini. Oleh karena itu maka dimungkinkan sekali informan berasal dari pihak-pihak diluar manajemen PDAM yang menjadi objek penelitian (Mulyana,2004:182).

Informan dalam penelitian ini adalah pihak-pihak ini yang terdiri dari jajaran manajemen perusahaan, dan pelanggan. Untuk lebih melengkapi data penelitian ini, sesuai kebutuhan data dilakukan wawancara dengan beberapa tokoh terkait misalnya anggota Dewan dan lain sebagainya.

\section{PEMBAHASAN}

\section{Kinerja Rendah: Terbelenggu Dalam Keterpurukan}

Ketika pertama kali hutang RDI digulirkan pada tahun 1990, semua pihak berasumsi dan berharap bahwa kinerja PDAM akan mengalami perbaikan dari tahun sebelumnya. Dua tahun sebelum pencairan, secara berturut-turut PDAM MAJU masih memiliki kinerja positif. Laba tahun 1993 dan 1994 tercatat masing-masing $\mathrm{Rp} 31.542 .410$ dan Rp 1.434.920 (Lihat Tabel 2).

Namun, selama 14 tahun terakhir kondisi perusahaan sangat menyedihkan. Tiga tahun pertama yaitu tahun1995 telah merugi hingga mencapai Rp 323.246.210. Tahun berikutnya kerugian terus berlanjut hingga mencapai angka milyar rupiah pada tahun 2000 dan tahun 2003. Pada tahun selanjutnya perusahaan tetap merugi meskipun jumlah menurun. Terhitung rata-rata kerugian yang dialami perusahaan selama enam belas tahun terakhir mencapai Rp 530.157.244 pertahun.

Tabel 2. Perkembangan Kerugian

\begin{tabular}{crrr}
\hline Tahun & \multicolumn{1}{c}{ Laba (Rugi) } & Tahun & \multicolumn{1}{c}{ Laba (Rugi) } \\
\hline 1993 & 31.542 .410 & 2001 & $(358.367 .630)$ \\
1994 & 1.434 .920 & 2002 & $(482.174 .620)$ \\
1995 & $(323.246 .210)$ & 2003 & $(1.135 .598 .660)$ \\
1996 & $(325.694 .520)$ & 2004 & $(875.235 .820)$ \\
1997 & $(562.551 .890)$ & 2005 & $(615.633 .150)$ \\
1998 & $(571.200 .720)$ & 2006 & $(309.481 .500)$ \\
1999 & $(876.417 .880)$ & 2007 & $(729.294 .570)$ \\
2000 & $(1.030 .056 .280)$ & 2008 & $(320.539 .740)$ \\
\hline \multicolumn{3}{c}{ Rata-rata Kerugian } & $(530.157 .244)$ \\
\hline
\end{tabular}

Sumber: Laporan Keuangan PDAM Maju 1993-2008

Jumlah kerugian yang terjadi secara beruntun pada gilirannya menyebabkan semakin tinggi rugi ditahan perusahaan. Sebagaimana dalam Tabel 3 menunjukkan bahwa mulai tahun 1993 hingga tahun 2008 rugi ditahan perusahaan mengalami kemerosotan. Jumlah kerugian ditahan pada tahun tersebut sungguh sangat fantastik yaitu mencapai angka $\mathrm{Rp}$ 8.583.729.131. 
Tabel 3. Perkembangan Rugi Ditahan

\begin{tabular}{|c|r|c|r|}
\hline Tahun & Laba (Rugi) Ditahan & Tahun & Laba (Rugi) Ditahan \\
\hline 1993 & $(69.670 .861)$ & 2001 & $(4.115 .771 .071)$ \\
1994 & $(68.235 .941)$ & 2002 & $(4.597 .945 .691)$ \\
1995 & $(391.482 .151)$ & 2003 & $(5.733 .544 .351)$ \\
1996 & $(717.176 .671)$ & 2004 & $(6.608 .780 .171)$ \\
1997 & $(1.279 .728 .561)$ & 2005 & $(7.224 .413 .321)$ \\
1998 & $(1.850 .929 .281)$ & 2006 & $(7.533 .894 .821)$ \\
1999 & $(2.727 .347 .161)$ & 2007 & $(8.263 .189 .391)$ \\
2000 & $(3.757 .403 .441)$ & 2008 & $(8.583 .729 .131)$ \\
\hline
\end{tabular}

Sumber: Laporan Keuangan PDAM MAJU 1993 - 2008

\section{Tarif Naik Bukan Solusi Bijak \\ Menutup Rugi}

Tarif menurut Bappenas (2003) dan YLKI (2004:20) adalah salah satu faktor yang menyebabkan PDAM memiliki kinerja rendah. Tarif yang ditentukan oleh hampir seluruh PDAM di Indonesia berada di bawah biaya produksi. Oleh karena masih di bawah biaya produksi maka pendapatan yang diterima tidak mampu menutup beban yang makin besar. Dengan demikian solusi yang harus dilakukan adalah perlu melakukan penyesuaian tarif secara bertahap agar mampu menutup biaya produksi.

Hasil kajian di atas secara logika memang bisa dibenarkan, namun dalam kenyataannya perlu dipertanyakan kembali. Sebagaimana yang terjadi dalam kasus PDAM MAJU dimana selama hampir enam belas tahun terakhir selalu menaikkan tarif. Tingkat tarif ditetapkan selalu berada di atas biaya produksi, namun kenyataannya kinerja perusahaan masih tetap terpuruk.

Tabel 4 dan Grafik 2 menjelaskan tentang perkembangan kenaikan tarif air minum dan kerugian yang dialamai perusahaan selama sebelas tahun terakhir. Berdasarkan data, meskipun sejak tahun 1998 tarif sudah ditetapkan berada di atas biaya produksi dan kemudian dilakukan penyesuaian tarif setiap dua tahun sekali, namun kondisi rugi tidak pernah hilang. Tarif dinaikkan tidak selalu menimbulkan keuntungan, malah terkadang menambah kerugian perusahaan

Tabel 4. Perkembangan Tarif dan Rugi PDAM MAJU

\begin{tabular}{|c|c|r|}
\hline Tahun & Tarif $(\mathrm{Rp})$ & \multicolumn{1}{|c|}{ Kerugian $(\mathrm{Rp})$} \\
\hline 1998 & 580,00 & 571.200 .720 \\
1999 & 580,00 & 876.417 .880 \\
2000 & 868,33 & 1.030 .056 .280 \\
2001 & 868,33 & 358.367 .630 \\
2002 & $1.583,33$ & 482.174 .620 \\
2003 & $1.583,33$ & 1.135 .598 .660 \\
2004 & $2.165,00$ & 875.235 .820 \\
2005 & $2.165,00$ & 615.633 .150 \\
2006 & $2.496,67$ & 309.481 .500 \\
2007 & $2.496,67$ & 729.294 .570 \\
2008 & $2.810,00$ & 320.539 .740 \\
\hline
\end{tabular}

Sumber: Data Tarif Divisi Teknik PDAM MAJU 
Berdasarkan hasil analisis ini, bisa disimpulkan bahwa tarif bukanlah satusatunya cara untuk mengatas kerugian perusahaan. Menaikkan tarif bukan cara bijak untuk memperoleh pendapatan sebanyak-banyaknya dan tanpa memperhatikan prinsip keterjangkauan dan kejujuran. Tarif yang tinggi, bahkan tertinggi di Jawa Timur tidak berarti jaminan bagi perusahaan kinerja mereka akan lebih baik.

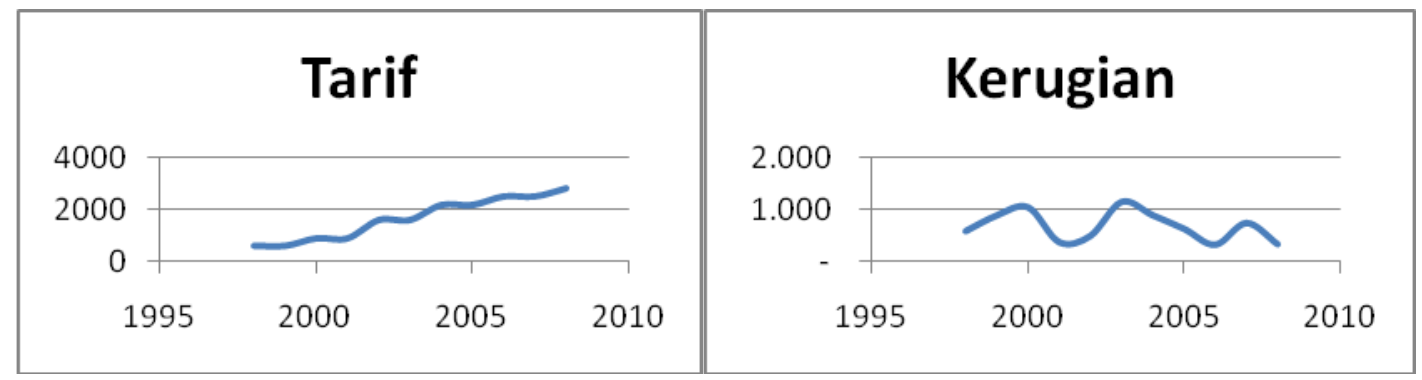

Grafik 2 Perkembangan Tarif dan Kerugian

Alam yang dimiliki pemerintah daerah setempat bukan menjadi penghalang untuk membuat terobosan usaha. Mereka membuka diri dan mau bekerjasama dengan pemerintah daerah lain. Dampaknya, tarif relatif terjangkau, kualitas dan kuantitas air bisa dinikmati oleh masyarakat pelanggan.

\section{Surat Penegasan: Buah Simalakama Meraih Laba}

Kerugian perusahaan selama enam belas tahun terakhir ini memperkuat persepsi masyarakat bahwa perusahaan publik selalu identik dengan ketidakefisienan dan tidak mandiri. Visi yang tidak ditetapkan secara jelas dan pemberian subsidi secara rutin dari pemerintah membuat perusahaan ini kurang motivasi dan tidak memiliki semangat mandiri.

Anggapan ini bagi perusahaan bukan sekedar wacana namun menjadi suatu kebenaran. Terlebih lagi, dengan adanya "Surat Penegasan" menjadi fakta utama bahwa perusahaan dimanjakan dengan dana dan jaminan kontinuitas dalam kondisi apapun. Surat penegasan ini berisi jaminan Bupati atas kelangsungan hidup PDAM dikarenakan kondisi kerugian yang makin besar. Adanya surat jaminan ini dibenarkan oleh pihak Direktur Umum dan Keuangan perusahaan:

Memang benar pak ada jaminan Bupati tentang keberlanjutan usaha PDAM. Coba lihat Surat Keputusan Bupati ini. Dengan surat ini ada jaminan PDAM tidak akan ditutup meskipun dalam kondisi rugi. SK ini sudah lama diminta oleh akuntan publik sebagai syarat jaminan keberlangsungan operasi perusahaan. Bagi kami selaku pengelola jaminan ini sangat berarti, karena konsekuensinya jika kami kekurangan dana maka kami akan mengajukan dana tambahan kepada Bupati. Dana untuk investasi transmisi pipa air, itu juga kami peroleh dari Pemda. Jadi tidak ada sedikitpun kekhawatiran kami akan di phk karena perusahaan rugi.

Surat penegasan ini memang menjadi "jaminan" bagi pihak manajemen untuk melangsungkan operasi perusahaan dalam kondisi apapun. Surat jaminan ini menjadi buah simalakama bagi perusahaan. Jika surat itu tidak ada, perusahaan tidak memiliki jaminan dana. Dipihak lain, surat itu secara langsung telah membuat motivasi kerja manajemen dan karyawan sangat rendah dan sempit. Mereka bekerja dengan motivasi apa adanya, perusahaan terus merugi, namun mereka juga tetap mendapatkan gaji tetap setiap bulan.

Dampak keberadaan surat jaminan terhadap motivasi kerja perusahaan dibenarkan oleh kepala bagian umum:

Surat jaminan ini kami minta setiap tahun karena menjadi salah satu syarat terbitnya opini akuntan publik. Artinya, setiap tahun pula Bupati sebagai kepala daerah mengeluarkan surat penegasan ini. Ya memang, SK itu juga ada kerugiannya, motivasi karyawan terutama sangat terpengaruh. Tidak 
seperti di perusahaan swasta, untuk mendapat keuntungan mereka akan kerja keras. Sebab jika rugi terus maka mereka sendiri yang akan teracam phk. Disini motivasi kerja teman-teman tidak sebaik di swasta. Mereka lebih mirip kerja di sebagai PNS. Datang saat sudah jam masuk lewat dan pulang sebelum waktunya. Bagi mereka, pekerjaannya adalah apa yang disuruh oleh pimpinan.

Ini merupakan salah satu hambatan psikologi yang tidak disadari oleh seluruh pihak di PDAM. Bisa jadi, inilah salah satu faktor lain yang membuat PDAM semakin terpuruk. Semangat kerja yang tanpa persaingan ditambah jaminan keberlangsungan operasi perusahaan dalam kondisi apapun, menyebabkan perusahaan bekerja ala kadarnya. Sifat ketergantungan yang sangat besar terhadap pemerintah daerah membuat manajemen dan karyawan bekerja layaknya bukan perusahaan. Bekerja tanpa target keuntungan dan terlepas dari jerat kerugian.

PDAM Rugi: Kesalahan Memerankan Kekuasaan Manajemen

Apakah ada perusahaan yang selama enam belas tahun rugi terus-menerus tapi masih bisa beroperasi? Apakah pantas disebut perusahaan rugi, jika masih bisa menggaji karyawan secara normal, masih bisa membayar rekening listrik, telepon, bayar konsultan pajak, bayar konsultan IT dan bayar auditor secara rutin? Tidak mungkin!!!. Inilah jawaban yang tepat dan logis dari pertanyaan-pertanyaan di atas. Kalaupun ada barangkali hanya ada dalam dunia khayalan dan di sinetronsinetron.

Bagi perusahaan, situasi dan kondisi yang digambarkan dalam pertanyaan-pertanyaan di atas adalah sebuah realitas. Aneh tapi nyata, itulah barangkali yang tepat diungkapkan untuk menggambarkan kondisi nyata di perusahaan ini. Meski dilanda kerugian terus-menerus sepanjang masa tapi perusahaan kokoh berdiri dan mampu membayar seluruh biaya-biaya rutin secara kontan.

Hasil penelusuran data dan wawancara dengan informan perusahaan menunjukkan bahwa sebenarnya secara likuiditas perusahaan memiliki kemampuan yang sangat besar. Disamping mampu membayar biayabiaya rutin secara kas, ternyata rata-rata jumlah kas dan setara kas yang dimiliki perusahaan setiap akhir tahun sangat besar yaitu mencapai 880 juta rupiah.

Tabel 5 menunjukkan situasi keuangan yang kontras antara jumlah kas dengan kemampuan perusahaan dalam membayar hutang RDI. Rata-rata kas hampir mencapai 1 milyar rupiah, ternyata perusahaan tidak mampu melunasi hutang RDI. Padahal jika mau, rata-rata jumlah saldo kas akhir periode yang besar ini mampu untuk melunasi hutang RDI dalam waktu yang tidak terlalu lama.

Tabel 5. Perbandingan Jumlah Kas dan Hutang RDI

\begin{tabular}{crr}
\hline Tahun & Jumlah Kas/Setara Kas & Jumlah Hutang RDI \\
\hline 2004 & 636.641 .595 & 6.933 .755 .765 \\
2005 & 955.606 .912 & 7.990 .607 .260 \\
2006 & 781.283 .435 & 9.440 .988 .482 \\
2007 & 605.394 .020 & 10.540 .944 .972 \\
2008 & 1.422 .422 .782 & 12.062 .604 .616 \\
\hline
\end{tabular}

Sumber: Laporan Keuangan PDAM MAJU

Jumlah kas yang besar ini lebih kontras jika dibandingkan dengan jumlah kerugian dan kontribusi pajak yang diberikan kepada Negara. Tabel 5 dan Tabel 6 secara jelas menggambarkan besarnya kas, namun tidak sebanding jumlah kerugian dan kontribusi pajak. Inilah mengapa sering terjadi guyonan dalam manajemen perusahaan, "enak ya... perusahaan rugi, tidak bayar pajak, 
uang banyak, gaji lancar, dijaminan tidak bubar."

Tabel 6. Perbandingan Jumlah Kerugian dan Kontribusi Pajak

\begin{tabular}{crc}
\hline Tahun & Jumlah Kerugian & Jumlah Pembayaran Pajak \\
\hline 2004 & $(875.235 .826)$ & Nihil \\
2005 & $(615.633 .155)$ & Nihil \\
2006 & $(309.481 .508)$ & Nihil \\
2007 & $(729.294 .576)$ & Nihil \\
2008 & $(320.539 .745)$ & Nihil \\
\hline
\end{tabular}

Sumber: Laporan Keuangan PDAM MAJU

Bagi perusahaan, situasi ini sepertinya "sangat diharapkan". Berdasarkan informasi yang dihimpun dari bapak Rkd, Direktur Umum dan Keuangan:

Bagi pihak manajemen, sebenarnya menginginkan kondisi rugi terus tapi uang kita banyak. Dengan rugi, berarti kami tidak perlu membayar pajak penghasilan yang jumlahnya cukup besar. Jumlah pembayaran pajak penghasilan yang dibayar ke kantor pajak lebih baik digunakan untuk operasional atau bayar gaji karyawan.

Makanya, saya tidak begitu senang adanya program pemutihan dan pembebasan beban hutang RDI oleh pemerintah pusat. Karena bagi kami, pembebasan itu berakibat kinerja laporan laba rugi menjadi tidak merugi lagi. Konsekuensinya jelas, secara bertahap kami akan laba dan selanjutnya akan membayar pajak penghasilan yang jumlahnya tidak sedikit.

Justru kondisi ini yang akan kami hindari, biarkan kinerja kami seakan rugi tapi didalam perusahaan sesungguhnya kami sehat karena kami sanggup bayar operasional, melakukan investasi yang diperlukan dan lain sebagainya (Wawancara, 28 Juli 2009)

Ketika dimintai pendapat tentang fenomena pembayaran pajak penghasilan yang nihil, penundaan hutang RDI dan jumlah kas yang melimpah, informan ini menyatakan:

Mengapa kas kami banyak dan melimpah, ini dikarenakan kami tidak membayar beban terbesar kami selama
15 tahun yaitu pembayaran pokok RDI, biaya adminsitrasi, bunga, denda administrasi dan bunga. Kami sengaja tidak membayar karena memang kami mendengar dari pembicaraan temanteman PDAM di Perpamsi bahwa akan ada program pemutihan beban hutang RDI. Kalau kami bayar secara tunai jumlahnya bisa 1 milyar lebih dalam setahun, itu berat bagi kami.

Coba anda hitung, jika saya menunda pembayaran beban maka berarti saya tetap membebankan biaya tersebut ke dalam laba rugi tapi kas nya tidak keluar. Sama-sama rugi membebankan, tapi kalau dibayar tunai kami tidak punya dana segar. Namun jika ditunda kami mendapat dua keuntungan, tidak bayar pajak penghasilan dan uang kas masih banyak. (Wawancara, 28 Juli 2009).

Tabel 7 menjelaskan tentang manfaat yang diperoleh jika perusahaan memiliki motivasi dan kemauan untuk menghindari denda keterlambatan. Berdasarkan hitungan jumlah dendadenda yang meliputi denda pokok, administrasi, dan commitment charge, berjumlah Rp 919.608.422 atau sekitar $74 \%$ dari beban hutang RDI. Jadi seandainya perusahaan mau membayar hutang dengan kas yang tersedia, maka jumlah beban setiap tahun akan berkurang. Dampaknya kerugian secara bertahap makin kecil dan mungkin akan mencapai laba pada tahun-tahun terakhir. 
Tabel 7. Prosentase Beban Adminsitrasi dan Denda Hutang RDI

\begin{tabular}{lrc}
\hline \multicolumn{1}{c}{ Keterangan } & \multicolumn{1}{c}{ Jumlah } & Prosentase \\
\hline Beban Administrasi & 330.852 .511 & $26 \%$ \\
Beban Denda Pokok & 215.604 .256 & \\
Denda Beban Administrasi & 697.176 .137 & $74 \%$ \\
Denda Beban Commitment Charge & 6.828 .029 & \\
\hline \multicolumn{1}{c}{ Total } & 1.250 .460 .933 & \\
\hline
\end{tabular}

Sumber: Laporan Keuangan PDAM MAJU

\begin{abstract}
Realitasnya, pihak manajeman tidak memiliki keinginan untuk menghindari denda-denda. Manajemen lebih suka terhadap kondisi perusahaan yang rugi secara pembukuan, namun sehat secara keuangan. Pilihan yang menguntungkan secara individu, namun secara kelembagaan mengorbankan kinerja perusahaan.
\end{abstract}

\section{Meski Rugi, Wajib Setor PAD: Inikah Keadilan Bagi Pemda?}

Meskipun dalam kondisi rugi, PDAM wajib membayar PAD ke pemerintah daerah, dari mana uangnya? Inilah pertanyaan besar yang menjadi perhatian dan kebingunan banyak pihak terhadap PDAM. Secara logika, tentu tidak mungkin dalam kondisi rugi PDAM masih mampu setor PAD ke Pemda. Tapi inilah realitas yang terjadi, perusahaan masih mampu membayar PAD selama bertahun-tahun. Tentu selama itu pula beban keuangan perusahaan semakin bertambah.

Tabel 8. Perbandingan Setoran PAD dan Kerugian PDAM

\begin{tabular}{lll}
\hline Tahun & PAD & Kerugian \\
\hline 2004 & 120.000 .000 & $(875.235 .826)$ \\
2005 & 132.000 .000 & $(615.633 .155)$ \\
2006 & 140.000 .000 & $(309.481 .508)$ \\
2007 & 87.500 .000 & $(729.294 .576)$ \\
2008 & 117.000 .000 & $(320.539 .745)$ \\
Rata-rata & 119.300 .000 & \\
\hline
\end{tabular}

Sumber: Data Laporan Keuangan PDAM MAJU

Berdasarkan data keuangan perusahaan pada Tabel 8, Jumlah setoran PAD perusahaan ke pemda selama lima tahun terakhir, rata-rata mencapai Rp 119.300.000 pertahun. Padahal pada tahun yang sama, jumlah kerugian perusahaan juga besar. Jadi ada kesan bahwa setoran ini diwajibkan dalam kondisi apapun. Nampak bahwa pihak PDAM sendiri tidak memiliki pilihan selain menyetor dana ke PAD Pemda.

Sehubungan dengan kewajiban perusahaan menyetor PAD ini, dua informan Direktur Umum dan Kepala Bagian Umum dan Keuangan, secara seragam menyatakan: Perusahaan ini milik Pemda, jika tidak menyetor PAD akan menjadi bumerang buat pimpinan. Jika tidak bayar maka kita akan dipecat untuk mengelola perusahaan ini. Setoran PAD bagi pimpinan menjadi ukuran kinerja. Jika tidak setor atau setorannya kecil itu, akan menjadi pertanyaan besar bagi Pemda kepada kami.

Saya tahu, mestinya dalam kondisi rugi perusahaan tidak perlu setor PAD ke Pemda. Tapi itu bentuk kompromi kami ke Pemda agar terus bisa di bantu dan dijamin keberlangsungan perusahaan ini. Dan juga untuk menunjukkan kinerja kita bahwa PDAM punya kontribusi ke PAD Pemda (Wawancara, 28 Juli 2009) 
Berdasarkan peraturan menteri dalam negeri, setoran PAD baru bisa dilakukan jika perusahaan mengalami laba. PAD bersumber dari bagian laba perusahaan bukan dari bagian rugi perusahaan. Hal ini berarti jika perusahaan laba maka ada kewajiban untuk memberikan sebagian laba ke kas Pemda. Namun sebaliknya, jika perusahaan rugi maka tidak perlu ada setoran ke Pemda.

"Keterpaksaan"

perusahaan menyetor PAD kepada Pemda ini mendapat sorotan dari Ketua Perpamsi, dalam suatu kesempatan: Berdasarkan peraturan yang baru, Perusahaan Daerah Air Minum (PDAM) tidak ada kewajiban menyetorkan keuntungan bagi peningkatan Pendapatan Asli Daerah (PAD). Karena dalam undang-undang Badan Usaha Milik Daerah (BUMD) tahun 2010, PDAM masuk dalam Perusahaan Umum Daerah (Perumda), bukan Persero.

Perusahaan yang diakui berdasarkan peraturan BUMD adalah perumda ada persero, namun Perumda dipegang 100 persen dipegang pemerintah. Sementara Perseroda dipegang swasta. Dalam peraturan tersebut PDAM masuk dalam Perumda, bila masuk Perumda maka PDAM tidak ada kewajiban harus memberikan keuntungan untuk peningkatan PAD. Melainkan berdasarkan ketentuan tersebut keuntungan harus dikembalikan ke dalam perusahaan, sebagai investasi dalam upaya peningkatan pelayanan kepada publik. Bila inventasi berasal dari keuntungan itu terus ditingkatkan maka harapannya, adalah peusahaan kian berkualitas dan mampu memberikan pelayanan yang terbaik kepada masyarakat. (Antara, 2 Pebruari 2010)

Karena dilakukan dengan penuh keterpaksaan itu maka tidak heran jika PDAM-PDAM melakukan segala macam cara untuk menyetor PAD. Tidak ada niat lain selain agar kinerja mereka mendapatkan penilaian yang bagus dari Pemda. Temuan Menteri Pekerjaan Umum tentang penyalahgunaan pinjaman luar negeri untuk setoran PAD ke Pemda setempat menjadi contoh praktek yang illegal. Bapak Djoko
Kirmanto menyampaikan temuannya dalam suatu pertemuan:

"Akibat kewajiban untuk menyetor kepada pemerintah daerah, PDAM kerap menyalahgunakan dana yang diserahkan oleh pemerintah pusat untuk menambah Pendapatan Asli Daerah (PAD). Padahal dana dari pemerintah pusat dialokasikan untuk meningkatkan investasi PDAM.

Temuan Dirjen kami atas pencarian dana yang telah dilakukan pemerintah pusat menunjukkan bahwa pada akhir tahun ketika dilakukan pengecekan terdapat aliran dana dari PDAM ke kas daerah. Itu berarti tidak ada dan yang digunakan untuk investasi. Itu hanya memindahkan DIPA (Daftar Isian Pelaksanaan Anggaran) Departemen Pekerjaan Umum ke daerah" (Kompas, 27 Agustus 2008).

Sungguh naïf jika praktek-praktek penyetoran PAD kepada Pemda ini dilakukan seperti ini. Mengejar keuntungan pribadi pimpinan di mata Pemda, mengorbankan institusi dan juga pelanggan.

\section{PDAM Rugi: Ulah Pelanggan Juga}

Dalam perspektif pelanggan barangkali tidak banyak yang memahami mengapa perusahaan mengalami kerugian. Hal itu disebabkan sejauh ini perusahaan belum mengungkapkan laporan keuangan kepada publik secara transparansi. Oleh karena itu pelanggan memiliki persepsi yang berbeda tentang kinerja keuangan perusahaan. Di mata pelanggan semua menyatakan dan yakin bahwa perusahaan seharusnya memiliki laba besar. Menurut mereka pembayaran rekening dilakukan secara rutin dan lancar, sementara kucuran air belum menunjukkan kualitas dan kuantitas yang diharapkan.

Pernyataan ini sebagaimana diungkapkan oleh ibu Tn seorang pelanggan yang berada di salah satu kelurahan Patemon di kota MAJU:

Saya kok tidak yakin bila PDAM rugi, saya dan mungkin pelangga lain bayar rekening air rutin dan jika saya bandingkan dengan kota lain mahal sekali disini. Rekening saya tidak pernah turun-turun dari angka 200.000 perbulan. Tapi meski saya bayar mahal dan rutin, air yang saya peroleh tak sebanding dengan mahalnya bayar. Mau 
tidak langagan disini tidak ada sumur, serba repot mas saya ini.

Air tidak pernah hidup lancar, kadang hidup kadang mati, giliran hidup hanya sedikit sekali. Itu tetangga saya bayar mahal juga tapi airnya keluar kalau malam jam 12 sampai jam 3, jadi lembur-lembur nungguin air (Wawancar, 14 Nopember 2009).

Kinerja perusahaan yang rendah tidak hanya bergantung pada manajemen namun juga dipengaruhi pihak luar perusahaan yaitu pemerintah daerah, legislatif serta pihak pelanggan. Oleh karena itu, untuk menilai kinerja tidak bisa hanya dipandang dari manajemen saja namun juga dari pihak lain. Pelanggan sebagai pihak yang sangat berkepentingan memiliki pengaruh besar terhadap kinerja perusahaan. Tidak hanya dari daya beli dan kepuasan pelanggan atas produk perusahaan, namun juga sikap pelanggan terhadap cara memperoleh produk dari perusahaan.

Bentuk-bentuk kecurangan pelanggan hingga saat ini banyak dijumpai, misalkan pelanggan tidak melaporkan water meter yang telah rusak, kolusi antara petugas pencatat meter dengan pelanggan untuk menekan biaya rekening, berlangganan dengan illegal, dan lain sebagainya.

Praktek-praktek pencurian air oleh pelanggan dibenarkan oleh Badan Pengawas Keuangan dan Pembangunan Perwakilan Propinsi Jawa Timur sebagaimana dalam laporan hasil pemeriksaan mereka:

"Perusahaan masih menderita kerugian terutama disebabkan tingkat kebocoran air yang tinggi. Perusahaan belum sepenuhnya dapat mengendalikan kebocoran pada tingkat kebocoran yang normal $20 \%$. Hal ini tampak dari jumlah kebocoran air sebesar 35,68\% melebihi batas normal.

Beberapa penyebab kondisi tersebut karena adanya meter air yang telah rusak yang lebih dari lima tahun belum ada peneraan, ada pelanggan yang tidak menggunakan meter air sehingga pembayaran rekening air dikenakan tarif rata-rata minimal, serta adanya indikasi pemasangan sambungan langgan illegal oleh oknum masyarakat (Laporan BPKP, 2007)

Berdasarkan laporan BPKP tersebut sebenarnya semua indikasi telah diungkap dan bisa dijadikan patokan untuk mendeteksi lebih jauh. Jika mau ditelusuri dan ada keinginan untuk diperbaiki, segala macam bentuk kesalahan dan penyimpangan itu dapat segera diatasi.

Contoh pola penyimpangan lain sebagaimana diakui oleh Bapak MA seorang pelanggan yang selama ini mungkin termasuk pelanggan yang sangat diuntungkan. Di tempat tinggal mereka air terus mengalir lacar dan pembayaran rekening lebih murah dibandingkan pelanggan lain, sebagaimana dituturkan:

Saya sudah lama jadi pelanggan PDAM hampir berpuluh-puluh tahun langganan. Alhamdulillah air saya tidak bermasalah sejak dari dulu hingga sekarang. Tetangga-tetangga dan temanteman di kantor saya kok ribut dengan airnya saya tidak tahu. Sepengetahuan saya pembayaran rekening air saya lumayan murahlah, dibandingkan dengan tetangga dan teman-teman. Dari dulu pembayaran air saya hampirhampir tidak berubah kalau ada ya naik naik dua atau tiga ribu. Saya juga tidak pernah ngecek meteran air karena sudah lama mati dan memang saya biarkan tidak melapor. Saya khawatir aja kalau misal saya lapor dan meteran air itu diganti bisa-bisa pembayaran air saya naik dan mungkin tidak seperti saat ini. Biarkan saja tidak saya beritahu ke PDAM, itukan tugasnya PDAM. Nah itu yang saya tidak tahu, apakah selama ini petugas PDAM yang ngontrol meteran itu tidak tahu atau memang tidak pernah ngecek ke tempat meteran. Karena memang tempat meteran air saya agak tersembunyi dan di dalam pagar jadi mungkin waktu petugas datang tidak melihat langsung. (Wawancara, 12 Agustus 2009)

Modus penyimpangan lain yang dapat dilakukan pelanggan adalah melakukan kolusi dengan karyawan PDAM. Hal ini sebagaimana diakui Ibu YY pelanggan yang bermukim di bagian pusat kota: 
Rekening air saya sekarang sudah turun, ini berkat teman senamku yang juga karyawan PDAM. Sebelum diturunkan biasanya rekening air saya tidak pernah berubah setiap bulannya yaitu 200 ribu rupiah, selama kira-kira 5 tahunan. Untungnya saya punya teman senam dan saya iseng-iseng tanya sama dia dan menjanjikan akan bantu. Suatu saat saya mau bayar rekening air, saya ketemu dulu dengan teman senam itu. Selanjutnya temanku langsung datang ke bagian penagihan dan kasir. Entah apa yang dibicarakan dengan mereka. Alhamdulillah pembayaran rekening langsung turun 100 ribu rupiah saat itu. (Wawancara, 12 Agustus 2009). Gambaran beberapa modus penyimpangan oleh pelanggan ini semata-mata ingin menunjukkan bahwa hingga saat ini permasalahan itu belum bisa diatasi oleh perusahaan, dan jika hal itu tidak segera diatasi maka perusahaan akan terus merugi. Sebaliknya jika ada keinginan untuk segera mengatasi "kenakalan" pelanggan sesuai prosedur aturan yang ada maka kinerja yang baik segera akan diraih perusahaan.

\section{PENUTUP}

Kerugian yang timbul seakan menjadi harapan dan kondisi yang meninabobokkan manajemen. Semua in merupakan akumulatif dari berbagai pengaruh, faktor dari dalam maupun dari luar perusahaan. Kerugian merupakan refleksi penggunaan kekuasaan (power) yang salah. Salah dalam membuat kebijakan hutang, salah tidak mengantisipasi dan mengatasi kelebihan jumlah karyawan, salah mempersepsikan misi ganda yang diemban.

Surat penegasan jaminan dari kepala daerah merefleksikan peran kekuasaan pemilik utama PDAM MAJU. Manajemen tidak kuasa untuk tidak menyetor PAD sehingga menyebabkan kinerja makin memburuk. Moralitas manajemen yang tidak amanah dan tidak professional dalam pengelolaan hutang, serta peran pelanggan dengan berbagai "modus kenakalan" semakin melengkapi derita yang dialami PDAM MAJU.

\section{DAFTAR PUSTAKA}

Ayudhia, Fika, 2008, Bebas Nilai Dalam Imu Pengetahuan, Artikel Lepas, 28 Agustus

Bailey, Derek T., 1988, Accounting in Socialist Countries, London: Routledge.

Burrel, G. \& Morgan, G, 1979, Sociological Paradigms and Organisational Analysis: Elements of The sociology of Corporate Life, London: Heinemann Educational Books.

Burchell, S., Clubb, C. \& Hopwood, A. G.,1985, Accounting in its Social Context: Towards a History of Value Added in the United Kingdom, Accounting Organizations and Society, pp. 381-413.

Chua, Wai Fong, 1986, Radical Development in Accounting Thought, The Accounting Review, LXI

Cooper DJ, And Shere,MJ, 1984, The Value Of Corporate Accounting Reports: Arguments For A Political Economic Of Accounting, Accounting, Organization And Society, Vol. 5 No. 1 Pp. 161-166.

Dougherty, James E \& Robert, P, 1981. Contending Theories of International Relations: A Comprehensive Survery. New York: Harper and Row Publisher Inc.

Ghozali , Imam (2004) Pergeseran Paradigma Akuntansi Dari Positivisme Ke Perspektif Sosiologis Dan Implikasinya Terhadap Pendidikan Akuntansi Di Indonesia. Dokumentation. Diponegoro University Press, Semarang.

Hopper, T., Cooper, D.J., Lowe T., Capps, T., \& Mouritsen, J. (1986). Management control and worker resistance in the National Coal Board: financial controls in the labour process. In D. Knights and $\mathrm{H}$. Willmott (eds.), Managing the Labour Process. (pp. 109-141). London: Gower.

Hopwood (1978), Towards an Organizational Perspective for the 
Study of Accounting and Information Systems, Accounting Organizations and Society, pp. 313.

Indriantoro, Nur, dan Bambang Supomo 1999, Metodologi Penelitian Bisnis: Untuk Akuntansi dan Manajemen, Edisi Pertama, BPFE, Yogyakarta

Irianto, Gugus, 2006, Privatisasi BUMN Di Indonesia: Pilihan Atau Keniscayaan? Telaah Dari Perspektif PEA, Proceeding, The Second Postgraduate Consortium On Accounting 2006, Brawijaya University Malang.

Kompas, 2001, Total Hutang PDAM Rp 3,4 Triliun, 16 Februari.

Kompas, 2003, Dari 243 PDAM yang Beroperasi Hanya 9 Persen yang Sehat, Kamis, 04 September 2003.

Kompas, 2006, 108 PDAM Tak Becus Susun Laporan Keuangan, 27 Agustus.

Kompas Mobile, 2007, 274 PDAM Di Indonesia Sakit, 28 Pebruari.

Kompas, 2008, 255 PDAM Dalam Kondisi Sakit, 28 Agustus.

Kompas, 2008, PDAM Bebas Setor ke Pemda, Rabu 27 Agustus.

Miller, Seafors, 1985, Intermediate Accounting, Illionois Second Edition, Richard D. Irwin, Inc.

Muhadjir, Noeng, 2000, Metodologi Penelitian Kualitatif, Rake Sarasin, Yogyakarta, Hal 196 - 204.

Mulyana, Deddy, 2003, Metodologi Penelitian Kualitatif Paradigma Baru Ilmu Komunikasi Dan Sosial Lainnya, Rosda Karya, Bandung.

Nasution, (1996), Metode Penelitian Naturalistik-Kualitatif, Penerbit NARSITO, Bandung.

Neimark, M Dan Tinker,T, 1986, The Social Construction Of Management Control System, Accounting, Organization And Society, Vol. 11 No. 4 Pp. 369-395.

Shaoul, Jean, 1997a, A Critical Financial Analysis Of The Performance Of Privatised Industries : The Case Of The Water Industry In England And Wales, Critical Perspectives On Accounting, 8, 479 - 505

Shaoul, Jean, 1997b, The Power Of Accounting Reflecting On Water Privatization, Accounting, Auditing
\& Accountability Journal, Vol 10 No. 3, 1997.

Suara Karya, 2010, Terkuaknya Skandal Lehman Brothers, edisi 15 Maret.

Sucipto, 2003, Penilaian Kinerja Keuangan,

http:/ / www.google.co.id/ / hl/ /id\&b iw // 1260\&bih //484\&q=cara menilai kinerja perusahaan \& aq f\&aqi //g10\&aql \&oq / / \&fp//8d7df18fd6542f58, Digitized by USU digital library

Tinker, T,1980, Towards A Political Economic Of Accounting: An Empirical Illustration of The Cambridge Controversies, Accounting, Organization And Society, Vol. 5 No. 1 Pp. 147-160.

Tinker, A. M., Merino, B. D. \& Neimark, M. D.,1982, The Normative Origins of Positive Theories: Ideology and Accounting Thought, Accounting Organizations and Society, pp. 167200.

Triyuwono, Iwan, 2000, Organisasi Dan Akuntansi Syariah, Yogyakarta, LKIS.

Wijaya, Andy Felta, 2003, Result Performace Measurement And Water Price Policy, Jurnal Ilmiah Administrasi Publik, Vol. IV, No. 1 September; 61-79.

Wijaya, Andy Felta, 2004, Evaluation Outcome Performance In An Indonesian Public Water Company : The Implication Of Cost Inefficiency And Price Policy For The Poor, Paper To The Australian Policy Studies Association Conference, University Of Adelaide 29 September - 1 Oktober 2004.

Wijaya, Andy Felta, 2005, Water As A Public Good In Indonesia: An Evaluation Of Water Supply Service Performance In An Indonesian Water Supply Entreprise As A Means To Addreas Social And Environment Justice, Concern Disertasi, Flinders University Australia 